\title{
FACTORS CAUSING BRAND FAILURE AND BRAND RELAUNCH A SECONDARY STUDY
}

\author{
Geeta Devi \\ Department of Management \\ Maharaja Agrasen University, Baddi, Himachal Pradesh, India
}

\begin{abstract}
An attempt has been made in this paper to know the various factors causing Brand Failure and how Brand Relaunch takes place. The data has been collected through secondary data by reviewing various research papers which would help us to know the various factors responsible for brand failure and how they again revive their brand through brand relaunch. This research paper would help the various marketers and manufacturers to understand the failure factors of a Brand and aspects to be considered while Brand Relaunch. Five hypothesis will be constructed out of which four will show the significant relationship which means that quality, advertisement, brand loyalty and consumer behavior will be the important factors for the success and failure of a brand. On the basis of this study Models are also framed for the factors causing Brand Failure and factors leading Brand Relaunch.
\end{abstract}

Keywords-Brand Failure, Brand Equity, Brand Relaunch, Consumer Behavior, Quality

\section{INTRODUCTION}

Brand is a term closely linked to a product or place's image and reputation in that it "captures the idea of reputation observed, reputation valued and reputation managed" (Anholt, 2010, p. 20). A brand is a name, term, sign, symbol or design used to recognize the products of one firm and to discern them from the products of the opponents. A buyer detects the product with the brand name and the seller gets the chance to earn goodwill in the market. Brand stimulate the buyer in making his buying decisions and eases his searching time in finding products with the desired features. A brand generally represent the quality and standard of the product. Brand helps a company to create an image of the product in the market and to get repeated patronage. Brand management refers to the systems that organizations employ to manage and grow the value of their brands (Low \& Fullerton, 1994).

Branding is the process of designing a product with the some recognizing name or mark or combination of both. It gives a distinct individuality to a product. It helps in meeting competition and helps in placing the product in the market in an effective way. There is a policy which is used when different type of products are produced by the same manufacturers as it helps in creating reputation, goodwill and image of the company as well as the products in the eyes of the customers and distributors.

But, of due to some technical and other reasons when the performance and quality of one product is reduced, it will distress the sales of other products of the company as the customer presumes same standard and quality of all the products.

Brand Equity refers to the additional value that a consumer attaches with the brand that is unique from all other brands available in the market. It is the goodwill that a brand has gained over a long period of time. It is the value of a brand in the minds of consumers.

\section{DIMENSIONS OF BRAND EQUITY}

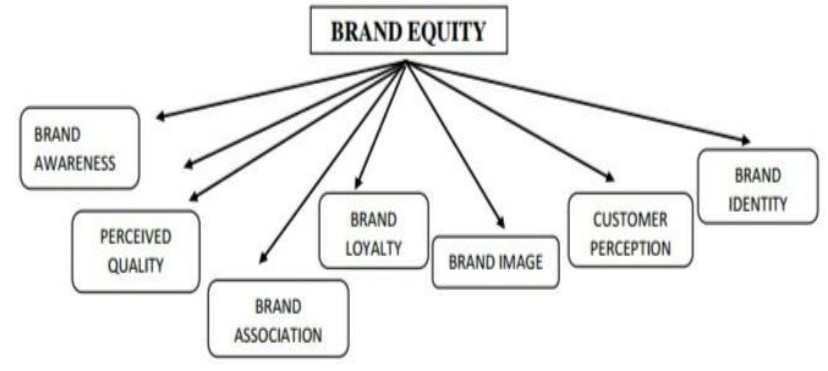

\section{BRAND RELAUNCH}

Brand relaunch means the restart and repositioning of a brand with the purpose of brand's strategic re-alignment. It helps a brand to come around with fresh energy by means of a revised brand strategy. The brand relaunch helps a brand to focus and address a more specific target group. Brand relaunch is important when the charm of a brand is declining constantly. It may lead to serious consequences such as slouching sales figures and dwindling competitiveness. A brand relaunch helps to encompass the life cycle of a brand but it bids not only opportunities but risks as well. The effect of brand relaunch must be considered. With brand relaunch it is important that the distinctive identity of a brand takes a central role during the relaunching process and the positioning of brand has to be credible, attractive, superior and sustainable.

WHY BRAND RELAUNCH? 


\section{International Journal of Engineering Applied Sciences and Technology, 2020 \\ Vol. 5, Issue 3, ISSN No. 2455-2143, Pages 482-486 \\ Published Online July 2020 in IJEAST (http://www.ijeast.com)}

The Brand has to be relaunched because of various reasons such as intense competition, legal issues, new technology, merger and acquisition, brand relevance and due to Globalization.

\section{BRAND RELAUNCHING - A BRAND BULIDING CONCEPT}

Re-launching a brand means thinking afar a new strategy, design or a new name. In marketing, in the life of brand there comes a stage, when brand needs to be re-worked and relaunched to proceed it to a different level. This happens with both the brands which are doing well and which may not be doing well to make it better or best. A brand has to go through various phases of development in their life. They need to be repositioned, restructured, rejuvenated and revitalized to expand sales, market shares and profits in the market.

\section{WAYS IN WHICH BRANDS CAN BE RELAUNCHED}

The first way to relaunch the brand is to keep all essentials of the mix alike but transpose the brand in the minds and hearts of customers. It means that the product, pricing and the distribution will remain same but the communication and the whole repositioning strategy modifies the perceived value of the brand. The essentials used would be in the area of the communication mix with packaging. This approach is followed when the consumers feel that the product doesn't match with their ambitions and needs but they acknowledged the product and found it reasonable and accessible.

The second way to relaunch the brand is to alter the channel and distribution strategy. The other elements may be working but the distribution channel may be futile due to the choice of in-appropriate channels or even ineffective trade boundaries and marketing plan. This can be related with the sales effort, sales organization and structure. This happens in cases where the product is recognized, its mindfulness is high but it is not accessible. Therefore, there is wastage of advertising money. In this case, renovating the distribution structure becomes necessary.

The third way to relaunch a brand would be to renovate very element of the marketing mix as well as the brand name, the product constituents and pricing, and bring it out with a novel price and bring it out as a new avatar. Brand Relaunching is an ordinary exercise but should be dealt vigilantly. It is recommended that if the brand is doing well because it's positioning, distribution and pricing are accepted by the customers and it is growing as per the desired objectives, then there is no need to tamper with something which is working.

\section{REVIEW OF LITERATURE}

\section{FACTORS CAUSING BRAND FAILURE}

Luffarelli J. et al. (2019) highlighted in their study that underestimating the importance of logo design and the power of descriptive design elements can, sometimes, be a costly mistake.

Setani T. et al. (2018) accentuated in their study that the media also has to pay attention to how they form their brand in the mind of the advertisers as shareholders. This is because it is related to financial or profit.

Kumar P. \& Rekhi S. (2017) highlighted in their study that Consumer buy branded product when quality is important to them. The Companies should do more advertisement than other means of publicity. Like T.V advertisement create more awareness about brand.

Hinestroza E. (2017) accentuated in her study that the market is not fully efficient, due to brand equity not being included on the balance sheet, not all available information is included in stock prices. The investors will adapt to the current conditions of the market, which is in accordance to the Adaptive Market Hypothesis.

Jain A. (2017) concluded that Consumer behavior is the strongest factor which affects branding of any product. A brand can be established as a brand if consumers are satisfied and are ready to purchase it.

Muqaddas M. et al. (2016) highlighted in their study that advertising and promotion have statistically significant impact on brand equity whereas R\&D doesn't make significant impact on brand equity. Based on the findings, it is observed that advertising is having the strongest impact on brand equity.

Shafqat H. \& Yasir R. (2016) highlighted in the study that the successful brand extension elements are Parent Brand Image, Parent Brand Fit, Parent Brand Strength, Marketing Support, Quality of Parent Brand and Parent Brand Consumer Experience.

Saeed K. et al. (2016) in their study found that indicators of brand failure can be categorized in two classes; one related to the Brand Promotional aspect and the other is Brand Performance in the market. The Reasons for brand failures are summarized into seven categories i.e., Branding Pillars, Branding Incompetence, Brand Performance, Brand Origin, Brand Image, Brand Competition and Brand Strategy. 


\section{International Journal of Engineering Applied Sciences and Technology, 2020 \\ Vol. 5, Issue 3, ISSN No. 2455-2143, Pages 482-486 \\ Published Online July 2020 in IJEAST (http://www.ijeast.com)}

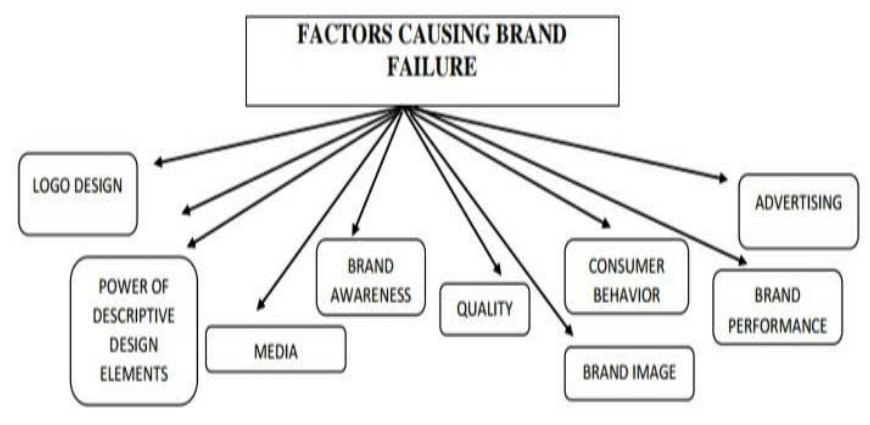

\section{FACTORS LEADING BRAND RELAUNCH}

Marta B. et al. (2019) accentuated in their study that repositioning a luxury fashion brand and changing the target audience requires a more radical approach. This not only causes a prominent changes in the brand but also simultaneously raises awareness.

Sohini N. et al. (2019) highlighted in their study the fact that rebranding has no effect on the firm's brand equity although brand equity has an influence on the firm's performance. The relationship between customer experience and firm performance is robust. This finding indicates that brand equity can have a strong influence without the influence of rebranding.

Peter et al. (2018) concluded in their study that customers' prior experience have a strong effect on the perception of a brand, since experience is part of the learning process and generates feelings and emotions.

Jeon J.(2017) in his research highlighted that aesthetic, functional and symbolic brands are separate constructs that combine to determine different types of emotional attachment and commitment related aspects of brand equity.

Satvati $\mathbf{R}$ et al. (2016) accentuated in their study that brand equity is associated with some aspects of consumer behavior including willingness to pay extra costs, brand preference and purchase intention. And there is a stronger relation between brand equity and brand preference than the two other variables. We can say that a strong brand creates added value for products that leads to customer preference in selection. In the later stages of purchase behavior, brand preference may lead to more payment and purchase intention by the consumer.

Gulzar F. (2015) concluded in her study that the main focus is consumer behavior. Hence the optimal strategy to avoid brand mistakes is one which is effective and only the marketing strategy based on consumer behavior can be effective. Thus companies should read there consumers well before any innovation of the products.

Ahmad R. et al. (2015) highlighted in their study that the digital media has a key role in creating brand loyalty since advertising has changed from traditional to digital so there is a much scope available in this area.

Kumar A. (2014) highlighted in his study that Brand equity is considered as an one of the vital aspect in determining the customer satisfaction, as it helps the companies in understanding the level of customer satisfaction and formulating the new strategies in order to customer delight.

G. Sriram \& C. Kathiaravan (2014) concluded in their study that customer's online involvement in social media has been improved nowadays. And also indicates that customer user interaction with the brand social media websites and image of brand among customers will also build and increase the reputation of brand among customers.

Buil I. et al. (2013) accentuated that brand equity dimensions inter-relate. Brand awareness positively impacts perceived quality and brand associations. Brand loyalty is mainly influenced by brand associations. Finally, perceived quality, brand associations and brand loyalty are the main drivers of overall brand equity. Findings also corroborate the positive impact of brand equity on consumers' responses.

Muhammad H. et al. (2012) concluded in their study that a new trend in the competitive market has emerged in the shape of launching a product through advertisement on media that is visual \& print and also through internet. Base line is to reach out to the consumer through all available means, to get maximum benefits.

Januja Q. (2009) highlighted in her study that consistently building strong, unique and favorable associations of the parent brand that translate into continuous fulfilling of 'brandpromise' will result in successful brand extensions as well as resist dilution in case of extension failure.

Sengun Y. et al. (2007) highlighted in their study that Market attractiveness positively influences the propensity of a brand to be launched into a new market. The results also suggest that companies are more likely to introduce additional brands in markets where they already have a presence. This study suggests companies should focus on acquiring both local and global experience to facilitate the launch of products and brands in the global marketplace.

Kumar R. \& Advani J. (2005) found in their study that marketers would have to balance the traditional axiomatic views of brand loyalty with the emerging dimensions of brand migration in a competitive context. 


\section{International Journal of Engineering Applied Sciences and Technology, 2020 \\ Vol. 5, Issue 3, ISSN No. 2455-2143, Pages 482-486 \\ Published Online July 2020 in IJEAST (http://www.ijeast.com)}

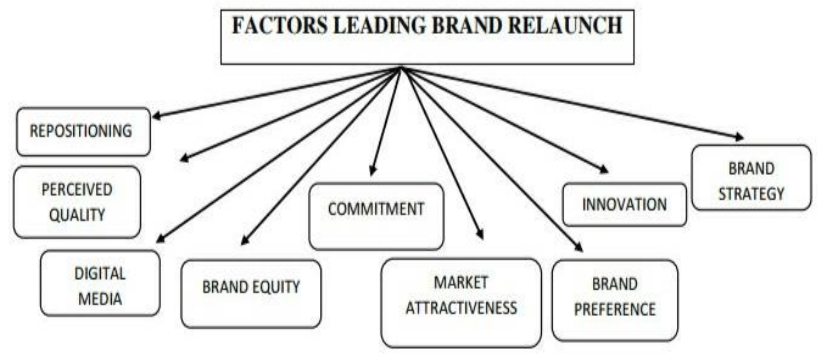

The hypotheses were developed based on previous research done. The hypothesis are as follows:

H1(a) There will be significant relationship between branding and consumer behavior.

H1(b) There will be significant relationship between brand equity and advertisement.

H1(c) There will be significant relationship between branding and customer satisfaction.

H1(d) There will be significant relationship between quality and brand loyalty.

H1(e) There will be significant relationship between R\&D and brand equity.

\section{RESULTS AND DISCUSSIONS}

The data has been collected through secondary study by reviewing various research papers, websites and books. Hypothesis will be proposed based on the previous research done.

\begin{tabular}{|l|l|}
\hline \multicolumn{1}{|c|}{ Hypotheses Proposed } & Result \\
\hline $\begin{array}{l}\text { H1 (a): There will be significant relationship between } \\
\text { branding and consumer behavior. }\end{array}$ & ACCEPT \\
\hline $\begin{array}{l}\text { H1 (b): There will be significant relationship between } \\
\text { brand equity and advertisement. }\end{array}$ & ACCEPT \\
\hline $\begin{array}{l}\text { H1(c): There will be significant relationship between } \\
\text { branding and customer satisfaction. }\end{array}$ & ACCEPT \\
\hline $\begin{array}{l}\text { H1 (d): There will be significant relationship between } \\
\text { quality and brand loyalty. }\end{array}$ & ACCEPT \\
\hline $\begin{array}{l}\text { H1 (e): There will be significant relationship between } \\
\text { R\&D and brand equity. }\end{array}$ & REJECT \\
\hline
\end{tabular}

This study provides many interesting results to be discussed. On the basis of previous studies five hypothesis will be proposed. Four out of five hypothesis were accepted.
This study shows that there will be significant relationship between branding and consumer behavior $\mathrm{H} 1$ (a) which means that branding affects consumer behavior. This is in line with the previous study done by Satvati R et al. \& Gulzar F. (2015, 2016). The H1 (b) hypothesis will also be accepted because there will be significant relationship between brand equity and advertisement. This is consistent with previous studies of Muhammad F.et al. \& Ahmad R. et al. (2015, 2016). The H1 (c) hypothesis will show the significant relationship between branding and customer satisfaction. This is consistent with previous studies of Kumar A. (2014). The H1 (d) hypothesis will be accepted because it will show significant relationship between quality and brand loyalty. This finding supports the previous studies of Kumar P. \& Rekhi S. (2017). The H1 (e) hypothesis will be rejected because it shows that there will be no significant relationship between $R \& D$ and brand equity. This is in line with the previous study done by Muhammad F. et al. (2016).

\section{CONCLUSION}

So, from the above study it has been concluded that Consumer behavior is the strongest factor which affects branding of any product. Brands to be developed should concentrate on some major factors which include quality, promotional tools, consumer behavior, brand equity and brand loyalty. These are some of the major factors which are responsible for the success and failure of a brand. It has also been concluded from this study that R\&D has no significant relationship with brand equity because customer prior experience related to the brand leads them to follow or being loyal to a specific brand.

\section{LIMITATIONS OF THE STUDY}

In every research there are unavoidable limitations. This research too has same. The research is only restricted to secondary data available. Hypothesis are only proposed in this study. Further there is scope for other researchers to conduct primary study on this topic because as such no enormous study has been done on this particular topic.

\section{REFERENCE}

[1] Luffarelli J. et al. (2019), "A study of 597 Logos shows which kind is most effective", Harvard Business School

[2] Blazquez M. et al. (2019), "The effects of rebranding on customer based brand equity", International Journal of Business and Globalization, 22(1):91

[3] Sohini N. et al. (2019), "The impact of corporate rebranding on brand equity and firm performance", Journal of Business and Retail Management, 13(4), DOI: 10:24052/jbrmr/v13is04/art-08 


\section{International Journal of Engineering Applied Sciences and Technology, 2020 \\ Vol. 5, Issue 3, ISSN No. 2455-2143, Pages 482-486 \\ Published Online July 2020 in IJEAST (http://www.ijeast.com)}

[4] Setani T. et al. (2018), “ The Effect of New Identity, New Image, and Repositioning as a process of Rebranding toward Brand Loyalty, Brand Associations, Perceived Quality a part of Brand Equity", RJOAS 4(76)

[5] Peter et al. (2018), "Factors affecting Purchase and Recommendation Willingness towards Brand Extension", IUP Journal of Brand Management Vol. $15(3)$

[6] Kumar P. \& Rekhi S. (2017), "The impact of Brand Equity on Business and Customer Perception", International Journal of Management and Commerce" 4(11): (685-693)

[7] Ashu J. (2017), "Factors affecting Branding in relation to Consumer Behavior: A case study of Micromax company in Metro City Jabalpur"

[8] Hinestroza E. (2017), "Brand Equity- A study on the relationship between brand equity and stock performance" Umea School of Business and Economics

[9] Jeon J. (2017), "The impact of brand concept on brand equity", Asia Pacific Jouranl of Innovations and Entreprenurship, Vol.11(2):233-245

[10] Saeed K. et al. (2016), "Brand failure: Factor Analytic Findings", Journal of Marketing Management and Consumer Behavior, 1(3):1-12

[11] Muqaddas M. et al. (2016), "Determinants of Brand Equity: An Empirical Study of IT Industry, SEAPractical Application of Science, 4(3):12:555-560

[12] Satvati R. et al. (2016), "Studying the relationship between Brand Equity and Consumer Behavior", International Review No. (1-2):153-163

[13] Shafqat H. \& Yasir R. (2016), "Brand Extension Succesful Elements: A Conceptual Framework", Journal of Business Administration and Education, Vol.8(1):23-35

[14] Gulzar F. (2015), "Brand Failures- When do Good Brands do Bad" A case study of Classic Example of Brand Failure: Pepsi café Chino, MIT-SOM PGRC KJIMRP $1^{\text {st }}$ International Conference (Special issue) pp.94-101

[15] Ahmad R. et al. (2015), "Impact of Digital Media on Brand Loyalty and Brand Positioning", New Media and Mass Communication, Vol.45:16-28
[16]Kumar A. (2014), "Brand Equity and Customer Satisfaction- A study of LG Television in Mysore District", International Journal of Management Research and Review, 4(5) :610-615

[17] Sriram G. \& Kathiaravan C. (2014), "Effect of Social Media and Factors Influencing a Brand's Reputation", International Journal of Innovative Research and Studies, Vol. 3(8)366-378

[18] Buil L. et al. (2013), "The influence of Brand Equity on Consumer responses", Journal of Consumer Marketing, 30(1):62-74

[19] Muhammad H. et al. (2012), "Factors affecting the Brand Recognition", Global Journal of Management and Business Research, 12(7) Version 1.0

[20] Jain A. (2010-11), "Principles of Marketing, VK Global Publications Ltd., pp no.195-216

[21] Januja Q. (2009), "Brand Extensions: What Work and What Doesn't", Journal of Business and Economics, Vol.1(1):93-112

[22] Anholt, S. (2010). Places: Identity, image and reputation. Houndsmills, United Kingdom: Palgrave Macmillan.

[23] Yeniyurt S. et al. (2007), "Factors influencing Brand Relaunch in a Global Marketplace", Journal of Product Innovation Management, 24(5):471-485

[24] Volckner et al. (2006). "Drivers of brand extension success." Journal of Marketing 70(2): 18-34

[25] Kumar R. \& Advani J. (2005), "Factors affecting Brand Loyalty: A study in an emerging market on fast moving consumer goods, Journal of Consumer Behavior, 4(2):251-275

\section{ACKNOWLEDGEMENT}

I wish to record my deep sense of gratitude and profound thanks to Dr. Urvashi Tandon, Associate Professor, Chitkara Business School, Rajpura for her keen interest, inspiring guidance, constant encouragement with my work during all stages to bring this research paper into fruition. I would also like to thanks the reviewers and editors for their reviews and support for publishing. 